\title{
CHARACTERISATION OF CONSTRUCTED WETLAND SUBSTRATES BY CHEMICAL SEQUENTIAL EXTRACTION AND X-RAY DIFFRACTION ANALYSES
}

\author{
Aisling D. O'Sullivan, Ronald Conlon, Bredagh Moran and \\ Marinus Otte
}

Aisling D. O'Sullivan (corresponding author: e-mail: aisling.osullivan@ canterbury.ac.nz), Natural Resources Engineering, Department of Civil Engineering, University of Canterbury, Private Bag 4800, Christchurch 8020, New Zealand; Ronald Conlon, Civil Engineering and Environmental Science, 202 West Boyd Street, The University of Oklahoma, Norman, OK 73019, USA; Bredagh Moran and Marinus Otte, Wetland Ecology Research Group, Department of Botany, Division of Biosciences. National University of Ireland, Belfield, Dublin 4.

Received 6 February 2004. Read 23

February 2005. Published 15 August 2005.

\section{INTRODUCTION}

Passive treatment technologies are categorised as those that operate principally on naturally occurring integrated and interdependent biogeochemical processes (Younger et al. 2002). They are characteristically operated by solar and microbial processes as vegetation (through photosynthesis), and microbes (e.g. bacterial sulphate reduction) help convert reactive wastes into non-reactive forms. Constructed (or treatment) wetlands are a type of passive treatment technology that can assist society in the management of its wastewater by relatively 'natural' means. Other passive treatment designs that assist in wastewater management include swales, which provide for runoff infiltration; stabilisation (detention) ponds, which promote gravity-driven precipitation; oxidation ponds, in which algae provide oxygen through photosynthesis; and permeable reactive barriers, which promote in-situ biochemical treatment of contaminated groundwater.

Constructed wetlands have been employed in treating wastewater for the removal of biological material (e.g. nutrients) (Hammer 1989; Moshiri
1993; Kadlec and Alvord 1989; Vymazal et al. 1999; Mitsch and Gosselink 2000) and nonbiological wastes, such as metals (Hedin et al. 1994; Gusek and Wildeman 2002; Younger et al. 2002) for a number of years. They can provide an efficient facility for treating wastewater, while simultaneously offering ancillary benefits such as ecological niches (DeBusk et al. 1996; Horstman et al. 1998; O’Sullivan et al. 2003). They can be of educational, recreational and spiritual value. Constructed wetlands were originally prescribed as simple oxidation ponds in which emergent and floating aquatic vegetation were planted (Tchobanoglous 1993). Most systems were designed for a plug flow scenario, where little attention was given to elucidating the 'black box' phenomena responsible for removal of the contaminants. As a result, numerous systems failed to meet the treatment efficacy expected, particularly for biological wastewater (Tchobanoglous 1993). In the past 25 years, technological designs for passively treating metal mine wastes using engineered wetlands evolved in complexity as researchers understood the biogeochemical processes behind the treatment (Gusek and Wildeman 2002). The development of constructed wetlands for mining 
wastewater treatment has been recognised as an economically feasible, ecologically acceptable treatment technology in recent decades (Hammer 1989; Kadlec and Alvord 1989; Gusek and Wildeman 2002; Younger et al. 2002). The concept that wetland ecosystems can serve as a sink for human-generated wastes has been referred to as a 'forged partnership' between nature and human activity (Mitsch and Gosselink 2000).

Although treatment wetlands have been documented in extensive detail, little work has been reported on the fate of the contaminants removed from the wastewater in the long-term (Faulkner and Richardson 1989; Baker et al. 1991; Beining and Otte 1996; Wood and Shelley 1999; Athay et al. 2003). While vegetation (through annual dieback) is crucial for renewing carbon supplies to sustain microbial activity in these systems, most of the metals and sulphur are retained in the substrates (Machemer et al. 1993; Wood and Shelley 1999; Mays and Edwards 2001) rather than absorbed by vegetation. It is important to know the speciation of contaminants retained in substrates of treatment wetlands because some forms, such as metal sulphides, are immobile and thus considered relatively unavailable to biota (Debusk et al. 1996; Wood and Shelley 1999; Chartier et al. 2001). As many constructed wetland systems attract a diverse biological community, it is essential to facilitate contaminant removal without placing biota at risk.

We performed chemical sequential extraction (SE) and X-ray diffraction (XRD) analyses on wetland substrates, sampled at varying depths, from four-and-a-half year old treatment systems. These analyses aimed to characterise metal and sulphur forms that accumulated over time. The SE analyses can provide information about the various chemical forms and their mobility (i.e. watersoluble, exchangeable, carbonate-bound, organic matter-bound and residual fractions), and this technique has been frequently reported elsewhere (Tessier et al. 1979; Carapeto and Purchase 2000). The XRD analyses can provide additional information about the relative abundance of each mineral identifiable in the substrates. The XRD process involves characterising crystalline materials in sediments by examining the patterns that occur when X-rays of a known wavelength act upon the randomly oriented powder derived from the sediment. The XRD pattern produced is essentially a fingerprint of the compounds in a sediment sample. Extensive detail on this procedure is reported elsewhere (Hanawalt and Rinn 1986; Hanawalt et al. 1986; Warren 1990). The Bragg Equation is used to decipher the crystalline peaks. It can be defined as $\mathrm{n} \lambda=2 \mathrm{~d} \sin (\Theta)$, where $\lambda=$ the wavelength of the $\mathrm{Cu}$ (1.54 angstroms) tube, $\mathrm{n}=1, \mathrm{~d}$ is the distance between crystal lattices and $\Theta$ is the angle through which data points are collected and interpreted between 3-70 degrees).

Substrates of the treatment wetlands referred to in this study remained net-reducing shortly (three months) after flooding and were usually highly reduced $(-300 \mathrm{mV})$ as determined by monthly redox potential measurements (O'Sullivan 2001). Four genera of sulphatereducing bacteria isolated from these anaerobic substrates were indicative of active biological sulphate reduction (O'Sullivan et al. 2003). Sulphate can serve as an electron acceptor in microbial respiration under anoxic conditions. Because the wastewater had high sulphate levels (c. $9.4 \mathrm{mM} \mathrm{1}^{-1}$ ) while the substrate contained substantial carbon supplies (for microbial action), reduced conditions (promoted initially by water logging) would be conducive to sulphate reduction. Because metal cations such as zinc and lead can bind with sulphide anions under such conditions, metal sulphides could form, and thus zinc, lead, iron and sulphate would be removed from the wastewater.

It was expected that the form of metals retained in the substrates would be relatively immobile due to these reduced (and circumneutral) substrate conditions. It was also hypothesised that greater metal concentrations would be found in the upper substrate layers as metals do not typically migrate to deeper levels (Miller et al. 1983; Debusk et al. 1996; Chagué-Goff and Rosen 2001).

\section{MATERIALS AND METHODS}

Two similar multicelled surface flow treatment wetland systems (each with an area of $36 \mathrm{~m}^{2}$ ) were constructed on-site at Tara Mines (OutokumpuZinc), Ireland. The two systems are referred to as system 1 (W1) and system 2 (W2). The only difference between systems was the quality of mine wastewater entering them, so that system 2 typically received greater zinc and lead concentrations $\quad\left(0.3-27 \mu \mathrm{mol} \quad \mathrm{Zn} 1^{-1} ; 0.3-\right.$ $\left.1.6 \mu \mathrm{mol} \mathrm{Pbl}^{-1}\right)$ compared with system 1 $\left(0.2-3.3 \mu \mathrm{mol} \mathrm{Zn} 1^{-1} ; 0.1-1.1 \mu \mathrm{mol} \mathrm{Pb} 1^{-1}\right)$ (O'Sullivan 2001). Flow rates were regulated at $1.51 \mathrm{~min}^{-1}$ for both systems, while the theoretical residence time was calculated in excess of 30 days. Each system comprised an inflow cell, a vegetated wetland cell and an outflow cell in series. Each cell had a $c .50 \mathrm{~cm}$ substrate base consisting of a mix of spent mushroom compost and fine gravel and had a hydraulic head of $c .25 \mathrm{~cm}$. Design specifications have been reported in detail elsewhere (O'Sullivan et al. 2000; O'Sullivan et al. 2004a). The treatment 
strategy behind the constructed wetlands design was to promote some slow flow over the surface (facilitating suspended solids precipitation) while providing some subsurface flow through the substrate (maximising substrate contact time) to facilitate biological sulphate reduction.

Substrates were sampled in the inflow cells of both constructed wetlands in 2002 at depth intervals of $0-5 \mathrm{~cm}, 5-10 \mathrm{~cm}$ and $10-15 \mathrm{~cm}$ below the flooded surface. A $2 \mathrm{~m}$-long PVC corer $(5 \mathrm{~cm}$ diameter $)$ was employed in each instance. Immediately upon sampling, extracted cores were fractionated into increments of $5 \mathrm{~cm}$ and all samples were kept frozen until analysis. The sampling procedure is documented in O'Sullivan et al. (2004b).

Samples for chemical sequential extraction analyses were analysed for various exchangeable and bound forms after following the extraction procedures described by Tessier et al. (1979), Otte and Wijte (1993), and Carapeto and Purchase (2000). Each sequential analysis involved subjecting samples to a digestion regime using a specific degrading solution and temperature. Metals were analysed by atomic absorption spectrophotometry (AAS) using a Unicam 929 AAS, which supported SOLAAR ATI software (version 5.25). All metal and sulphur extraction procedures are documented in O'Sullivan et al. (2004b). Sulphur in the substrates was collected as acid volatile sulphide (AVS), using a digestion and volatilisation technique following Allen et al. (1993) and subsequently quantified colorimetrically after Cline (1969).

For the XRD analyses, dried sediment samples were finely ground using a mortar and pestle and smeared onto a glass slide in a paste using pure alcohol. Dried mounted samples were analysed using a Rigaku automated wide-angle X-ray diffractometer coupled to a copper anode $(40 \mathrm{kV} /$ $30 \mathrm{mV}$ ) and a graphite monochromometer. Data were analysed with Jade Software (version 3.1) and identified using the ICDD-PDF (International Centre for Diffraction Data-Powder Diffraction File).

\section{RESULTS AND DISCUSSION}

\section{SAMPLE REFINEMENT AND METALS ACCUMULATION}

Detailed baseline physical and chemical analyses of substrates sampled in all cells of both systems are previously reported (O'Sullivan et al. 2004b). The purpose of this study was to examine the mineralogical fate of metals retained in the substrates after four-and-a-half years and to compare the results with the chemical extraction data. Samples analysed in this study by XRD and chemical sequential extraction (SE) were selected based on their higher metal content. We wished to obtain 'most concentrated' samples to reveal the mineralogical fate of the metals because successful XRD analysis requires a metal content of c. 5\% (Barry Weaver, College of Geosciences, University of Oklahoma, pers. comm.). As a result, substrates from the inflow cells in both treatment systems were selected for the coupled XRD and SE analyses as the metal amounts in wetland and outflow samples was usually less than $1 \%$.

Metal concentrations, particularly lead, in the inflow substrates $\left(16 \mu \mathrm{mol} \mathrm{Pb} \mathrm{g}^{-1} ; 13 \mu \mathrm{mol} \mathrm{Zn}\right.$ $\mathrm{g}^{-1}$ ) were greater than in substrates of the vegetated cells $\left(11 \mu \mathrm{mol} \mathrm{Pb} \mathrm{g}^{-1} ; 12 \mu \mathrm{mol} \mathrm{Zn} \mathrm{g}^{-1}\right)$ or outflow cells $\left(6 \mu \mathrm{mol} \mathrm{Pb} \mathrm{g}{ }^{-1} ; 11 \mu \mathrm{mol} \mathrm{Zn} \mathrm{g}^{-1}\right)$ in the subsequent water path (O'Sullivan et al. 2004b). These observations can be explained as follows. Firstly, a long hydraulic retention time $(c$. 30 days) under reducing conditions $(-300 \mathrm{mV})$ promoted metal removal early on in the treatment train. Dunbabin et al. (1988) found that a greater retention time in microcosm wetlands contributed to greater metal retention, and they attributed this to a greater contact time with the substrate. Moreover, actual concentrations entering subsequent cells along the path of treatment were therefore lower. Other researchers have found that metal concentrations, of lead in particular, are greater in constructed wetland sediments closest to the inflow source (Debusk et al. 1996). The same researchers also found that the upper sediments consistently had higher concentrations of lead compared to deeper sediments. Since metal contamination in soils is a cumulative process, the higher lead concentrations in the inflow cell substrates were attributed to greater lead concentrations in the receiving water in those cells over time (O'Sullivan et al. 2004b). Miller et al. (1983) also found that greater lead loadings in such systems resulted in greater lead retention in the substrates and noticed preferential lead retention compared to zinc. Debusk et al. (1996) initially noticed gradual increases in sediment $\mathrm{Pb}$ concentrations in the top $0-5 \mathrm{~cm}$ profile, followed by a sharp increase in concentrations over time. They attributed this observation to sediment 'maturation' (i.e. progressively reducing conditions coupled with metal biogeochemical change as dynamics of metal adsorption changed to metal binding).

\section{CHEMICAL SEQUENTIAL EXTRACTIONS}

The total metal concentrations (sum of all fractions) in sediments were above the background levels of $1.8 \mu \mathrm{mol} \mathrm{Zn} \mathrm{g}{ }^{-1}$ and $0.25 \mu \mathrm{mol} \mathrm{Pb} \mathrm{g}{ }^{-1}$ reported in 
uncontaminated wetland substrates (Kadlec and Alvord 1989), while the values for iron were much greater than background levels of $3.0 \mu \mathrm{mol}$ $\mathrm{Fe} \mathrm{g}^{-1}$ (Fig. 1). Concentrations of metals were far greater in the residual (e.g. sulphide-bound) forms for $\mathrm{Zn}$ (Figs 1a, 1b), Pb (Figs 1c, 1d) and Fe (Figs 1e, 1f), while concentrations in the other sediment fractions were all low (below background levels). These data show that metals and sulphide removed from solution were safely immobilised in the substrates and were probably unavailable for biological uptake in these systems. Debusk et al. (1996) found that lead (and cadmium) were predominantly retained in wetland sediments as metal sulphides and deduced that metal bioavailability and toxicity were consequently limited. They observed no adverse effects on Gambusia fish reproduction or cattail (Typha) and duckweed (Lemna) biomass production in their experiments in constructed wetlands subjected to metal-laden water. We attributed contaminant removal in our systems to the prevailing alkaline $\mathrm{pH}$, reducing substrate conditions and carbon and sulphate availability, which facilitated metal sulphide formation over time (Machemer and Wildeman 1992; Machemer et al. 1993). This corroborates with other studies that found that sediment processes govern metal recycling in sediments of similar wetland systems (Debusk et al. 1996; Chartier et al. 2001).

Residual (Res) concentrations of Zn (Figs 1a, 1b) and $\mathrm{Pb}$ (Figs 1c, 1d) were usually lower, with increasing depth in both treatment systems. This may be due to the fact that heavy metals are not very mobile and so were predominantly retained in the upper sediment layers. These findings are in accordance with other studies (Miller et al. 1983; Sidle et al. 1991; Chagué-Goff and Rosen 2001). For residual $\mathrm{Fe}$ (Figs 1e, 1f), there was some nonpatterned spatial variability between depths, which is expected in wetland soils (Doyle and Otte 1997; Mistch and Gosselink 2000). The chemical extraction analyses showed that under consistently reduced substrate conditions, metal and sulphides were bound predominantly as metal-sulphide complexes. These data indicate that if conditions are maintained, waterlogged and circumneutral $(\mathrm{pH})$, contaminant toxicity is not likely as metals are retained in substrates, and biota are not as exposed to these substrates compared with water. It should be noted that, in the systems described here, a relatively long hydraulic retention time (HRT) of c. 30 days contributed to maintaining anaerobic conditions and to achieving successful contaminant removal.

\section{X-RAY DIFFRACTION ANALYSES}

The same substrates sampled for chemical sequential extractions were analysed for mineral content by
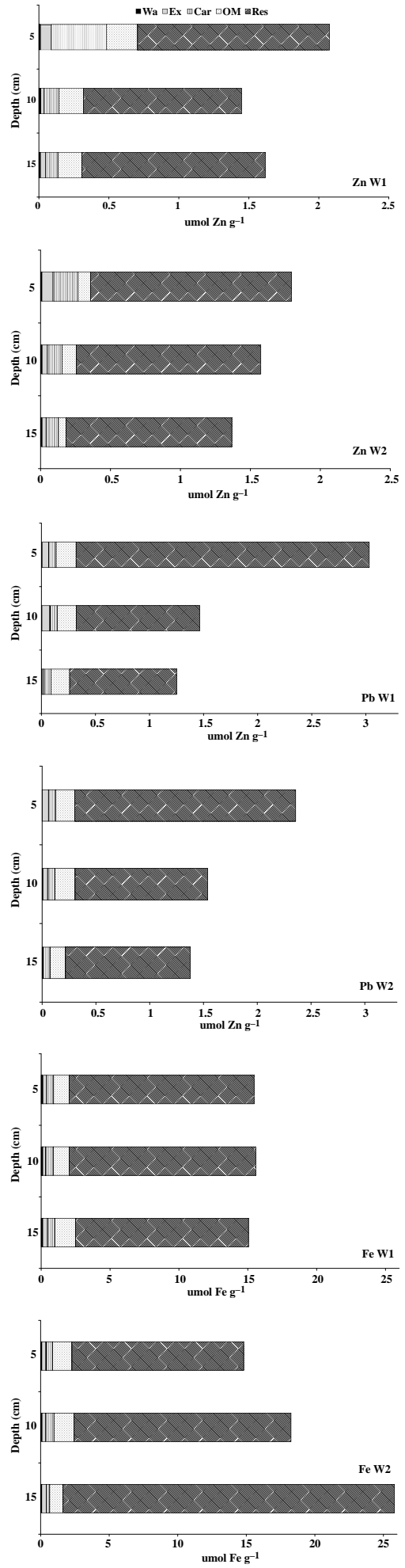

Fig. 1-Water soluble, exchangeable, carbonate bound, organic matter bound and residual fractions are presented for $\mathrm{Zn}, \mathrm{Pb}$ and $\mathrm{Fe}$ in substrates of the inflow cells of treatment wetlands 1 (W1) and 2 (W2) at 4.58 years after flooding. Concentrations are given as means $(n=3)$ for depths of $0-5 \mathrm{~cm} \mathrm{(5),} 5-10 \mathrm{~cm}(10)$ and $10-15 \mathrm{~cm}(15)$. Actual residual fractions are $\times 10^{1}$ for $\mathrm{Zn}$ and $\mathrm{Pb}$ and $\times 10^{2}$ for Fe. 

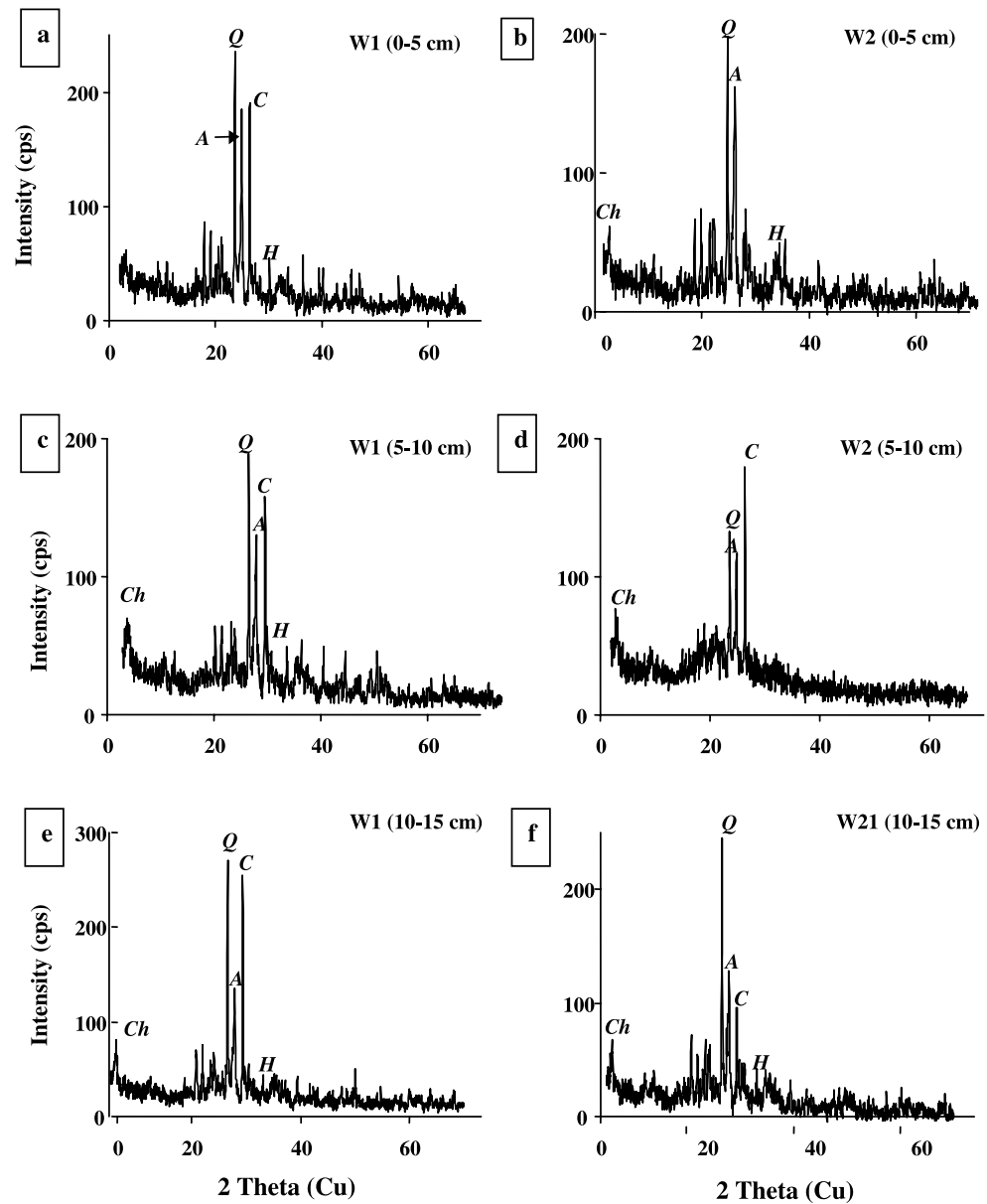

Fig. 2-X-ray diffraction analyses of substrates from the inflow cells of treatment wetlands 1 (W1) and 2 (W2) at 4.58 years after flooding. Intensities vs. $2 \Theta(\mathrm{Cu})$ data are presented for sediments analysed at depths of $0-5 \mathrm{~cm}, 5-10 \mathrm{~cm}$ and $10-15 \mathrm{~cm}$. The identifying peaks for each mineral are indicated as follows: $Q=$ quartz; $C=$ calcite; $A=$ albite; $C h=$ chlorite; $H=$ hematite. cps = counts per second. The Bragg Equation is used to decipher the crystalline peaks. It can be defined as $n \lambda=2 \mathrm{~d} \sin (\Theta)$, where $\lambda=$ the wavelength of the $\mathrm{Cu}(1.54$ angstroms) tube, $n=1, \mathrm{~d}$ is the distance between crystal lattices and $\Theta$ is the angle through which data points are collected and interpreted between 3-70 degrees).

XRD. The predominant sediment minerals observed at all depths, as indicated by their identifying peaks, were quartz $\left(\mathrm{SiO}_{2} ; \mathrm{d}=3.34\right)$, calcite $\left(\mathrm{CaCO}_{3} ; \mathrm{d}=3.03\right)$, albite $\left(\mathrm{NaAlSiO}_{8} ; \mathrm{d}=\right.$ $3.21)$ and chlorite $\left(\left(\mathrm{Mg}_{5} \mathrm{Al}\right)(\mathrm{SiAl}) \mathrm{O}_{10}(\mathrm{OH})_{2}\right) ; \mathrm{d}=$ 14.2) (see Fig. 2). Other (minor) peaks on the $\mathrm{X}$-rays are secondary peaks associated with each mineral. The main minerals are derived from the grit component of the substrate mix used during the construction of the treatment systems in 1997, which was relatively inert, as determined from chemical analyses conducted prior to construction (O’Sullivan 2001).

No detectible quantities of galena $(\mathrm{PbS})$, sphlaerite $(\mathrm{ZnS})$, pyrite $\left(\mathrm{FeS}_{2}\right)$, marcasite $(\mathrm{FeS})$, cerrusite $\left(\mathrm{PbCO}_{3}\right)$, siderite $\left(\mathrm{FeCO}_{3}\right)$ or hydrozincite $\left(\mathrm{Zn}_{5}(\mathrm{OH})_{6}\left(\mathrm{CO}_{3}\right)_{2}\right)$ could be identified in the sediments, although these minerals might be expected in such substrates over a longer period of metal accumulation
(Younger et al. 2002). However, hematite $\left(\mathrm{Fe}_{2} \mathrm{O}_{3}\right)(\mathrm{d}=2.69)$ was suspected in the sediments of both treatment systems at a variety of depths (Fig. 2). Hematite is a major iron ore mineral that usually forms after iron consolidation of many years (Younger et al. 2002). Some researchers report that amorphous iron materials, which result from iron-precipitation in water at low temperatures, can convert to goethite, the precursor to hematite. Hedin (2002) characterised iron sludge from a treatment wetland receiving iron-laden coal mine drainage as predominantly goethite $(\mathrm{FeOOH})$. Younger et al. (2002) reported that under circumneutral conditions in such wetlands, a combination of X-ray amorphous iron hydroxide and goethite typically forms. It is certain that an iron hydroxide formation was characterised, but the highly amorphous nature of the substrates meant that any accurate identification of minerals was difficult, with the exception of hematite. 
Nonetheless, some of the iron that was removed from the wastewater was retained as a hydroxide, and this implies that some oxygenation of the substrates occurred.

It is possible that the upper $0-5 \mathrm{~cm}$ of substrate contained micro-aerobic zones resulting from oxygen diffusion from the overlying inflow water. Deeper sediment samples could have become locally aerobic due to radial oxygen loss from the rhizomatous plants Typha latifolia and Phragmites australis, which is a well-documented phenomenon (Dunbabin et al. 1988; Brix and Schierup 1990; Jacob and Otte 2003). As a result, iron oxides could have formed in these sediment layers through the oxidation and hydrolysis of ferrous iron in solution. Nonetheless, redox measurements and identification of sulphatereducing bacteria indicated that substrates were predominantly anaerobic. Doyle and Otte (1997) emphasised the importance of $\mathrm{Fe}$ oxide (through co-precipitation) and organic matter fractions in wetland soils as means of immobilising heavy metals, particularly in vegetated microenvironments. The predominant minerals identified from the substrate grit (quartz, calcite, albite and chlorite) masked minor amounts of metal sulphide and iron oxide minerals that formed in these substrates. Furthermore, due to the amorphous nature of wetland substrates resulting from the high organic content, unambiguous identification of the mineral content was difficult for these systems.

\section{ACID VOLATILE SULPHIDE (AVS)}

Substrates from the inflow cells of both treatment systems were also sampled at two depths for determination of bound, yet reactive, sulphide concentrations measured as AVS (Fig. 3). There was considerable spatial variation in AVS concentrations, ranging between $39 \mu \mathrm{mol} \mathrm{g}^{-1}$ and $272 \mu \mathrm{mol} \mathrm{g}^{-1}$. However, since background concentrations typically measure $<2 \mu \mathrm{mol} \mathrm{S}^{2-}$ $\mathrm{g}^{-1}$ (Broderius and Smith 1977), a substantial amount of reduced sulphur accumulated over time in these treatment wetlands. This was attributed to high sulphate loadings in the inflow water, coupled with a high HRT and carbon availability conducive to sulphate reduction. The SE analyses showed that most sulphate ended up as bound metal sulphide, in accordance with other studies.

Sulphide:metal (S:Metal) ratios in substrates analysed at both depths, in each inflow cell, are given in Table 1. Ratios of sulphide:metal were significantly greater than 1 , with the exception of iron. This implies that toxicity is not likely, at least for zinc and lead in these substrates, which is a widely documented conclusion and is explained by

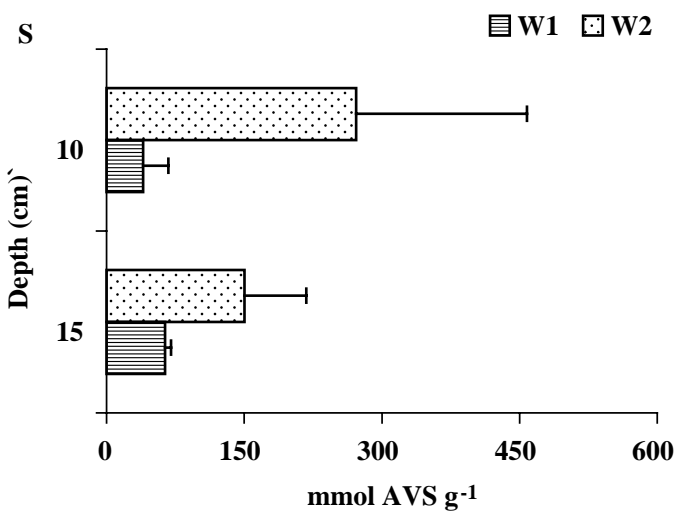

Fig. 3-Acid volatile sulphide (AVS) concentrations in substrates of the inflow cells of treatment wetlands 1 (W1) and 2 (W2) at 4.58 years after flooding. Concentrations are given as means + standard deviations $(n=3)$ for depths of $0-10 \mathrm{~cm} \mathrm{(10)}$ and $>15 \mathrm{~cm} \mathrm{(15).}$

the fact that available metal cations will rapidly bind to prevailing reactive sulphide anions under reduced conditions (Allen et al. 1993; Machemer et al. 1993; Debusk et al. 1996; Wood and Shelley 1999). However, since sulphide:iron ratios were usually less than 1, this may suggest that iron toxicity could occur in these systems. Since most of the iron was actually derived from the grit component of the substrate after rigorous chemical digestion (O'Sullivan 2001), iron is already immobilised in residual mineral form, and so toxicity is not likely.

Results from this study show that under reducing substrate conditions, such as those in similarly designed treatment wetlands with a relatively high HRT, toxic metals and sulphate can be removed from solution and retained in the substrate. The majority of the metals and sulphate removed were characterised as metal sulphides,

Table 1-Sulphide:metal ratios for $\mathrm{Zn}, \mathrm{Pb}$ and $F e$ at depths of $10 \mathrm{~cm}$ and $15 \mathrm{~cm}$ in the inflow cells of both treatment systems (W1 and W2). Values are derived from the mean concentration (in $\mu \mathrm{mol} \mathrm{g}^{-1}$ ) for each element.

\begin{tabular}{lccr}
\hline Depth $(\mathrm{cm})$ & Sulphide:metal ratios & $W 1$ & $W 2$ \\
\hline 10 & $\mathrm{~S}: \mathrm{Zn}$ & 27.4 & 173.2 \\
$\mathrm{~S}: \mathrm{Pb}$ & 27.2 & 176.6 \\
$\mathrm{~S}: \mathrm{Fe}$ & 0.3 & 1.5 \\
& $\mathrm{~S}: \Sigma \mathrm{Zn}+\mathrm{Pb}+\mathrm{Fe}$ & 0.25 & 1.5 \\
15 & $\mathrm{~S}: \mathrm{Zn}$ & 39.5 & 109.6 \\
$\mathrm{~S}: \mathrm{Pb}$ & 50.9 & 110.2 \\
& $\mathrm{~S}: \mathrm{Fe}$ & 0.4 & 0.6 \\
& $\mathrm{~S}: \Sigma \mathrm{Zn}+\mathrm{Pb}+\mathrm{Fe}$ & 0.4 & 0.5 \\
\hline
\end{tabular}


which are not very available to biota due to their strongly bound nature. This is important as constructed wetland systems often serve as an ecological habitat for biota in addition to acting as efficient treatment facilities. Since metal sulphides are not readily bioavailable, the adoption of treatment wetlands under these conditions does not seem to pose a risk to ecological communities (defined as a set of interaction species within an ecosystem).

While a combination of chemical SE and XRD analysis techniques is ideal for comprehensively characterising these substrates, there are limitations in using XRD on amorphous, organically rich wetland substrates that have a metal content of less than $5 \%$. Most of the sediments sampled from the treatment systems had elemental $(\mathrm{Zn}$ or $\mathrm{Pb})$ contents less than $1 \%$, with the exception of Fe (6-14\%). Therefore, we recommend that XRD analyses are only feasible when substrates of treatment wetland systems receive significantly large (beyond amounts in this study) metal loadings. Additionally, it is worth considering 'refining' samples for analysis by pretreatment to remove as much organic content as possible under a high temperature regime. In conclusion, we found XRD a useful and inexpensive complementary tool for examining the mineral and chemical structure of the wetland substrates that had metamorphosed over time in this study.

\section{ACKNOWLEDGEMENTS}

We thank Robert Turner and Barry Weaver in the College of Geosciences at the University of Oklahoma for permission to use the XRD machine and their assistance. We also acknowledge Declan Murray from the Department of Zoology, National University of Ireland, Dublin, for his involvement in the project. Financial support to conduct this work was provided in the form of a Post-Doctoral Fellowship from the Higher Education Authority in Ireland (2002-3).

\section{REFERENCES}

Allen, H., Gongmin, F. and Baolin, D. 1993 Analysis of acid volatile sulphide (AVS) and simultaneously extracted metals (SEM) for the estimation of potential toxicity in aquatic sediments. Environmental Toxicology and Chemistry 12, $1441-53$.

Athay, D., Nairn, R. and Strevett, K. 2003 Mine drainage treatment wetland substrate analysis. In R.I. Barnhisel (ed.), Proceedings of the $20^{\text {th }}$ Meeting of the American Society for Surface Mining and Reclamation, 2-16. Billings, MT, USA. American Society for Mining and Reclamation.

Baker, K., Fennessy, S. and Mitsch, W. 1991 Designing wetlands for controlling coal mine drainage: an ecologic-economic modelling approach, Ecological Economics 3, 1-24.

Beining, B. and Otte, M. 1996 Retention of metals originating from an abandoned lead-zinc mine by a wetland at Glendalough, Co. Wicklow, Biology and Environment 96 (B), 117-26.

Brix, H. and Schierup, H.-H. 1990 Soil oxygenation in constructed reed beds: the role of macrophyte and soil-atmosphere interface oxygen transport. In P. Cooper and B. Findlater (eds), Constructed wetlands in water pollution pontrol, 53-65. Wiltshire, UK. Wrc Swindon.

Broderius, S. and Smith, L., Jr 1977 Relative toxicity of free cyanide and dissolved sulphide forms to the fathead minnow (Pimephales promelas). Journal of Fish Research Board Canada 34, 2323-32.

Carapeto, C. and Purchase, D. 2000 Use of sequential extraction procedures for the analysis of cadmium and lead in sediment samples from a constructed wetland. Bulletin Environmental Contamination and Toxicology 64, 51-8.

Chagué-Goff, C. and Rosen, M. 2001 Using sediment chemistry to determine the impact of treated wastewater discharge on a natural wetland in New Zealand. Environmental Geology 40, 141123.

Chartier, M., Mercier, M. and Blais, J. 2001 Partitioning of trace metals before and after biological removal of metals from sediments. Water Research 35 (6), 1435-44.

Cline, J. 1969 Spectrophotometric determination of hydrogen sulphide in natural waters. Limnology and Oceanography 14, 454-8.

Debusk, T., Laughlin, R., Jr and Schwartz, L. 1996 Retention and compartmentalization of lead and cadmium in wetland microcosms. Water Research 30 (11), 2707-16.

Doyle, M. and Otte, M. 1997 Organism-induced accumulation of iron, zinc and arsenic in wetland soils. Environmental Pollution 96, 1-11.

Dunbabin, J., Pokorny, J. and Bowmer, K. 1988 Rhizosphere oxidation by Typha dominigensis Pers. in miniature artificial wetland filters for metal removal from wastewater. Aquatic Botany 29, $303-17$.

Faulkner, S. and Richardson, C. 1989 Physical and chemical characteristics of freshwater wetland soils. In D. Hammer (ed.), Constructed wetlands for wastewater treatment, 41-72. Chelsea, MI, USA. Lewis.

Gusek, J. and Wildeman, T. 2002 A new millennium of passive treatment of acid rock drainage: advances in design and construction since 1988. In D. Barnhisel and M. Collins (eds), Proceedings of the $21^{\text {st }}$ Meeting of the American Society for Surface Mining and Reclamation, 9th - 13th June, 935-51. Lexington, KY, USA. American Society for Mining and Reclamation.

Hammer, D. 1989 Constructed wetlands for wastewater treatment, municipal, industrial and 
agricultural. Proceedings from the First International Conference on Constructed Wetlands for Wastewater Treatment. Chelsea, MI, USA. Lewis.

Hanawalt, J.D. and Rinn, H.W. 1986 . Identification of crystalline minerals. Power Diffraction Journal 1 (1), $2-6$.

Hanawalt, J.D, Rinn, H.W. and Frevel, L. 1986 Chemical analysis by X-ray diffraction. Power Diffraction Journal $\mathbf{1}$ (2), 2-14.

Hedin, R. 2002 Recovery of marketable iron oxide from mine drainage. In D. Barnhisel and M. Collins (eds), Proceedings of the $19^{\text {th }}$ Annual American Society of Mining and Reclamation (ASMR) Conference, 517-26. Lexington, KY, USA.

Hedin, R., Nairn, R. and Kleinmann, R. 1994 Passive treatment of coal mine drainage. Information Circular \# 9389, 34. Bureau of Mines, US Department of the Interior.

Horstman, A., Nawrot, J. and Woolf, A. 1998 Mine-associated wetlands as avian habitat. Wetlands, 18 (2), 298-304.

Jacob, D. and Otte, M. 2003 Conflicting processes in the wetland plant rhizosphere: metal retention or mobilization? Water, Air and Soil Pollution (Focus) 3, 91-104.

Kadlec, R. and Alvord, H. 1989 Treatment wetlands. CRC Press, FL, USA. Lewis.

Machemer, S. and Wildeman, T. 1992 Adsorption compared with sulphide precipitation as metal removal processes from acid mine drainage in a constructed wetland. Journal of Contaminant Hydrology 9, 115-31.

Machemer, S., Reynolds, J., Laudon, L. and Wildeman, T. 1993 Balance of S in a constructed wetland built to treat acid mine drainage. Applied Geochemistry 8, 587-603.

Mays, P. and Edwards, G. 2001 Comparison of heavy metal accumulation in a natural wetland and constructed wetlands receiving acid mine drainage. Ecological Engineering 16, 487-500.

Miller, W., McFee, W. and Kelly, J. 1983 Mobility and retention of heavy metals in sandy soils. Journal of Environmental Quality 12 (4), 579-84.

Mitsch, W. and Gosselink, J. 2000 Wetlands. New York. Van Nostrand Reinhold.

Moshiri, G. 1993 Constructed wetlands for water quality improvement. London. Boca-Raton. Lewis.

O'Sullivan, A. 2001 Constructed wetlands for passive biological treatment of mine tailings water at Tara Mines, Ireland. PhD thesis, Division of Biosciences (Department of Botany), National University of Ireland, Dublin.

O'Sullivan, A., Murray, D. and Otte, M. 2000 Rehabilitating mine tailings water using constructed wetlands. In L. Daniels and S. Richardson (eds), Proceedings of the $17^{\text {th }}$ Annual Meeting of the American Society for Surface Mining and Reclamation, 438-45. Tampa, FL, USA. American Society for Mining and Reclamation.

O'Sullivan, A., Murray, D., Otte, M. 2003 Ecological development of constructed wetlands built for treating mine water at Tara Mines, Ireland. In D. Barnhisel (ed.), Proceedings of the $20^{\text {th }}$ American Society of Mining and Reclamation (ASMR) Conference, 945-60. Kentucky, USA. American Society for Mining and Reclamation.

O'Sullivan, A.D., Murray, A.D. and Otte, M.L. 2004a Removal of sulphate, zinc and lead from alkaline mine wastewaters using pilot-scale compost wetlands at Tara Mines, Ireland. Mine, Water and the Environment 23 (2), 58-65.

O'Sullivan, A., Murray, A. and Otte, M. 2004b Accumulation and fate of contaminants $(\mathrm{Zn}, \mathrm{Pb}$, $\mathrm{Fe}$ and S) in substrates of wetlands constructed for treating mine wastewater. Water, Air and Soil Pollution 157, 345-64.

Otte, M. and Wijte, A. 1993 Environmental variation between habitats and uptake of heavy metals by Urtica dioica. Environmental Monitoring and Assessment 28, 263-75.

Sidle, R., Chambers, J. and Amacher, M. 1991 Fate of heavy metals in an abandoned lead-zinc tailings pond: II. Sediment. Journal of Environmental Quality 20, $752-8$.

Tchobanoglous, G. 1993 Constructed wetlands and aquatic plant systems: research, design, operational and monitoring issues. In G. Moshiri (ed.), Constructed wetlands for water quality improvement, 23-34. London. Boca-Raton. Lewis.

Tessier, A., Campbell, P. and Bisson, M. 1979 Sequential extraction procedure for the speciation of particulate trace metals. Analytical Chemistry $\mathbf{5 1}$ (7), 844-51.

Vymazal, J., Brix, H., Cooper, P., Haberl, R., Perfler, R. and Laber, J. 1999 Removal mechanisms and types of constructed wetlands. In J. Vymazal, H. Brix, P. Cooper, G. Green and R. Haberl (eds), Constructed wetlands for wastewater treatment in Europe, 17-66. Leiden, Netherlands. Backhuys.

Warren, B. 1990 X-ray diffraction, 2nd edn. New York. Dover.

Wood, T. and Shelley, M. 1999 A dynamic model of bioavailability of metals in constructed wetland sediments. Ecological Engineering 12, 231-52.

Younger, P., Banwart, S. and Hedin, R. 2002 Mine water: hydrology, pollution, remediation. London. Kluwer Academic.
The subvention granted by the National University of Ireland, Dublin, towards the cost of publication of papers by members of its staff is gratefully acknowledged by the Royal Irish Academy. 